\title{
POTENSI TANAMAN JEWAWUT SEBAGAI SUMBER KARBOHIDRAT TERBARUKAN DAN BIOAKTIVITASNYA SEBAGAI ANTI HIPERTENSI
}

Potentials of Jewawut as Renewable Carbohydrat Source and Bioactivity as Anti Hypertension

\section{Giotama Demando, Becek Hamisah dan Zulia Marseli}

Departemen kimia, Jurusan Matematika dan Ilmu Pengetahuan Alam, Fakultas Sains dan Teknologi, Universitas Jambi

Email: khamisahsaman3424@gmail.com

\begin{abstract}
Jewawut is one of the plants that has the potential to be developed in order to strengthen food security as a source of carbohydrates instead of rice. This plant is spread almost all over Indonesia such as Buru Island, Jember, South Sulawesi Majene and other areas. Jewawut contains $74.16 \%$ carbohydrates higher than wheat which is only $69 \%$. This shows that jewawut is a potential source of functional food, especially as an energy source. Jewawut plants contain tannin phytochemical compounds which are secondary metabolites as antihypertensive compounds. Therefore, this article aims to explain how the cultivation of jewawut plants and their bioactivity properties against hypertension. The research method carried out in the form of literature studies, using sources or literature relevant to the problems found.
\end{abstract}

Keyword: Jewawut, Food Security, hypertension, Tannin

\begin{abstract}
Abstrak
Tanaman Jewawut merupakan salah satu tanaman yang berpotensi untuk dikembangkan dalam rangka memperkuat ketahanan pangan sebagai sumber karbohidrat pengganti beras. Tanaman ini tersebar hampir di seluruh Indonesia seperti pulau Buru, Jember, Sulawesi Selatan Majene dan daerah lainnya. Jewawut mengandung karbohidrat $74,16 \%$ lebih tinggi dibanding gandum yang hanya $69 \%$. Ini menunjukkan bahwa jewawut berpotensi sebagai sumber pangan fungsional, terutama sebagai sumber energi. Tanaman jewawut mengandung senyawa fitokimia tanin yang merupakan senyawa metabolit sekunder sebagai antihipertensi. Oleh karena itu, artikel ini bertujuan untuk menjelaskan cara budidaya tanaman jewawut dan sifat bioaktivitasnya terhadap penyakit hipertensi. Metode penelitian yang dilakukan berupa studi literature, dengan menggunakan sumber-sumber atau literature yang relevan terhadap permasalahan yang ditemukan.
\end{abstract}

Kata Kunci: Jewawut, Ketahanan Pangan, Hipertensi, Tanin

PENDAHULUAN

Ketahanan pangan (food

security) adalah kondisi terpenuhinya

pangan bagi rumah tangga yang

tercermin dari tersedianya pangan

secara cukup, baik jumlah maupun

mutunya, aman, merata dan

terjangkau. Hal ini merupakan salah

satu isu penting berkaitan dengan

ketersediaan pangan (availability dan

stability), distribusi (accessibility), dan serapan pangan (food utilization) yang pada akhirnya mempengaruhi ketahanan sosial, stabilitas sosial, ketahanan nasional serta stabilitas ekonomi termasuk pengendalian inflasi (harga) secara umum (Peraturan Pemerintah No. 68 Tahun 2002).

Berdasarkan data Badan Pusat Statistik (2018), data luas panen padi di Indonesia sebesar 10,9 juta

Potensi Tanaman Jewawut Sebagai Sumber Karbohidrat Terbarukan Dan Bioaktivitasnya Sebagai Anti Hipertensi - Giotama. D, Becek. H, Zulia. M| 355 
hektar, dengan produksi beras Jambi 1.349 hektar (BPS Prov sebesar 32,42 juta ton beras. Jambi, 2017).

Sedangkan konsumsi beras nasional

Tanaman Jewawut merupakan sebesar 29,6 juta ton. Selisih produksi dan konsumsi beras hanya 2,85 juta ton, dinilai tidak dapat memenuhi kebutuhan karena tidak semua beras digelontorkan petani ke pasaran. Produksi padi di Provinsi Jambi sekitar 500.021ton GKG. Menurut data Dinas Pertanian Provinsi Jambi (2012), sawah terluas terdapat di Kabupaten Tanjung Jabung Timur namun produktivitas padi per hektar-nya terendah karena terkait kualitas sumber daya lahan sawah yang sebagian besar terkontaminasi besi (Pirit), sedangkan produktivitas sawah tertinggi adalah Kabupaten Kerinci yang disebabkan pengelolaan dan sistem irigasi yang ada. Luas lahan sawah di Provinsi Jambi pada tahun 2017 seluas 133.868 hektar. Lahan sawah terluas di Provinsi Jambi terdapat di Kabupaten Muaro Jambi (23.194 hektar), diikuti oleh Kabupaten Tanjung Jabung Timur dan Kerinci masing-masing 22.637 hektar dan 18.915 hektar, sedangkan paling sedikit di Kota salah satu tanaman yang berpotensi untuk dikembangkan dalam rangka memperkuat ketahanan pangan sebagai sumber karbohidrat pengganti beras. Jewawut memiliki keunggulan dibandingkan dengan tanaman sumber karbohidrat lain, seperti dapat tumbuh pada hampir semua jenis tanah termasuk tanah kurang subur, tanah kering, mudah dibudidayakan, umur panen pendek dan kegunaannya beragam (Suherman et al., 2009). Jewawut mengandung karbohidrat 74,16\% lebih tinggi dibandingkan gandum yang hanya 69\% (Rauf dan Lestari, 2009). Selain itu, jewawut juga mengandung senyawa tanin yang dapat dijadikan sebagai antihipertensi, dimana berdasarkan Menurut data Kementerian Kesehatan RI (2018), sebanyak $34,1 \%$ masyarakat Indonesia dewasa 18 tahun ke atas terkena hipertensi. Berdasarkan data BPS Provinsi Jambi, jumlah kasus hipertensi di Provinsi Jambi sebanyak 122.198 kasus, yang 
merupakan kasus terbanyak ketiga di Jambi (BPS Prov Jambi, 2018).

\section{METODE PENELITIAN}

\section{Jenis Penelitian}

Penelitian ini termasuk jenis penelitian studi literature, dengan menggunakan sumber-sumber atau literature yang relevan terhadap permasalahan yang ditemukan. Referensi yang diperoleh dijadikan dasar atau acuan untuk penelitian di lapangan.

\section{Waktu dan Tempat}

Penelitian dilakukan di Fakultas Sains dan Teknologi Universitas Jambi. Penelitian dimulai dari $21 \mathrm{Mei}$ 2018 hingga 28 Mei 2018.

\section{Metode Pengumpulan Data}

Teknik yang dilakukan untuk mengumpulkan data dalam penelitian ini yaitu studi literature yang merupakan suatu teknik pengumpulan data dengan menghimpun dan menganalisis dokumen-dokumen, baik dokumen tertulis, gambar maupun elektronik. Jenis data yang digunakan berupa data sekunder, yaitu data yang bersumber dari buku, jurnal dan internet. Data sekunder yang dibutuhkan berupa potensi jewawut di Provinsi Jambi, cara budidaya tanaman jewawut, kandungan karbohidrat dari tanaman jewawut dan potensi jewawut sebagai anti hipertensi.

\section{Budidaya Jewawut \\ Persiapan Benih}

Tanaman jewawut dapat diperbanyak dengan biji, dengan cara menabur atau dimasukkan kedalam lubang tugal Kebutuhan benih sekitar 8-10 kg/ha. Jewawut yang berukuran biji besar diduga termasuk jenis pear millet (Pennisetum glaucum). Sedangkan jewawut berbiji kecil diduga termasuk millet jenis Panicum miliaceum atau proso millet dan Panicum ramosum atau bronstop millet. Varietas jewawut yang paling banyak dibudidayakan adalah minna, delima, emas, dan rambutan.

\section{Pengolahan Tanah}

Tanaman Jewawut tidak membutuhkan jenis tanah khusus untuk pertumbuhannya, oleh sebab itu pengolahan tanah yang akan dipergunakan sebagai lahan penanaman jewawut dapat dibagi pada 3 kategori sesuai kondisi lahan yang ada: 
1. Lahan yang baru perlu dilakukan pembersihan seluruh bagian tanaman atau gulma, kemudian membajak atau mencangkul untuk membantu membersihkan semua bagian tanaman yang ada serta

memberi penggemburan tanah sehingga perakaran jewawut lebih mudah berkembang.

2. Lahan dengan tingkat kesuburan sedang, dapat dilakukan dengan membersihkan gulma yang ada dan mencangkul sedikit bagian tanah yang subur guna mencegah tanah yang banyak humus tidak tertanam kembali kebagian yang dalam.

3. Lahan dengan tingkat kesuburan baik, dapat dilakukan dengan sistem TOT (Tanpa Olah Tanah) dengan menggunakan herbisida atau dengan membersihkan gulma secara konvensional.

Tanah yang telah diolah sebaiknya dibuat guludan sesuai kebutuhan dan kondisi tanah dengan tujuan memperbaiki drainase dan mencegah penggenangan air. Panjang guludan disesuaikan dengan panjang lahan, tinggi tumpukan tanah/gulu dan sekitar 25-
$30 \mathrm{~cm}$ dengan lebar dasar sekitar 30-40 cm. Jarak antara guludan tergantung pada kecuraman lereng, kepekaan erosi tanah, dan erosivitas hujan. Guludan dapat diperkuat dengan menanam rumput atau tanaman perdu.

\section{Penanaman}

Sama halnya dengan sorgum, benih jewawut tidak disemaikan tetapi dapat langsung di tanam pada lahan penanaman dengan jumlah benih yang ditanam sebanyak satu jumput atau malai dalam satu lubang tanam. Jarak tanam yang cocok untuk tanaman jewawut pada luas areal $2 \times 3$ meter adalah $75 \times 20 \mathrm{~cm}$ atau $70 \times 25 \mathrm{~cm}$.

\section{Pemeliharaan}

1. Pemupukan

Tanaman jewawut adalah tanaman yang dapat hidup pada input minim, seperti pupuk, namun untuk memberikan hasil maksimal pemupukan dapat dilakukan dengan menggunakan pupuk Urea, TSP dan $\mathrm{KCl}$. Pemupukan dilakukan dua tahap, yaitu $1 / 3$ bagian takaran urea ditambah seluruh TSP dan $\mathrm{KCl}$ diberikan pada umur 7-10 hari dan 
2/3 bagian urea diberikan pada umur tanaman 21 hari.

\section{Penyulaman}

Tujuan penyulaman adalah untuk mengganti tanaman yang pertumbuhannya kerdil, mati serta terkena serangan hama dan penyakit. Penyulaman dilakukan dengan memindahkan tanaman yang baik dari tumpukan tanaman dengan mencabut secara hati-hati agar seluruh akar dapat tercabut. Penyulaman dilakukan setelah 7 hari setelah penanaman.

3. Penyiangan, pemangkasan dan pemasangan ajir.

Tujuan penyiangan adalah membersihkan gulma yang telah tumbuh agar tidak terjadi persaingan akan unsur hara dengan tanaman pokok, sambal dilakukan pemangkasan pada tunas baru tanaman jewawut yang tidak produktif kemudian ajir dipasang agar pertumbuhan jewawut lebih kuat, ajir dipasang setelah 2-3 minggu setelah tanam. Pemangkasan kedua dilakukan setelah 2-3 minggu pemangkasan pertama.
4. Pengairan

Penyiraman di lakukan untuk membantu pertumbuhan tanaman. Penyiraman ini sebaiknya dilakukan 2 kali sehari agar tanaman tersebut tidak mengalami kekeringan selama partum-buhannya.
5. Pengendalian Hama dan Penyakit

Tanaman juwawut termasuk tanaman yang tahan terhadap serangan hama dan penyakit. Ada beberapa jenis hama dan penyakit yang menyerang, namun apabila tanaman ini dirawat dengan baik kecil kemungkinan akan terserang. Oleh karena itu tindakan preventif sangat dianjurkan agar tanaman tidak terserang hama yang sering susah dikendalikan adalah hama burung. Teknik pengendalian hama dan penyakit jewawut yaitu sebagai berikut

a. Pyricularia setariae

Penyakit ini biasanya menyerang tanaman saat musim hujan. Pada daun tumbul gejala berupa pin kepala kecil yang direndam air berupa titik-titik kekuningan yang berubah bentuk melingkar dalam waktu 2-3 hari dengan 
warna di tengah titik keabuabuan dikelilingi oleh cokelat gelap. Pengendaliannya berupa ketika titik awal terlihat, langsung semprot dengan fugisida, semprotkan nitrogen setelah semprotan fungisida.

b. Karat

Karat disebabkan oleh jamur Uromyces setariae italia. Penyakit ini mempengaruhi tanman pada semua tahap, meski kerusakan lebih rentan ketika infeksi terjadi sebelum jewawut berbunga. Karat dapat pula terlihat pada daun, batang dan batang daun. Pengendaliannya berupa memusnahkan induk semang jamur dan menyemprotkan mancozeb dengan dosis 2,5 $\mathrm{g} /$ liter air, segera setelah gejala awal muncul untuk mengurangi keparahan penyakit ini.

c. Luka Api

Luka api disebabkan oleh Ustilago crameri. Jamur memengaruhi sebagian besar biji-bijian dalam sori pada bunga dan bagian basal palea, kadang bagian ujung dari spike dapat terkena. Pengen- daliannya berupa menyeduh biji dalam 2\% larutan tembaga sulfat atau $0,5 \%$ formalin selama 30 menit. Merawat benih dengan arbendazim dengan dosis $2 \mathrm{~g} / \mathrm{kg}$ benih (Ilmudasar, 2018).

\section{Panen}

Ciri-ciri tanaman jewawut siap panen yaitu biji sudah bernas dan keras, daun atas mulai menguning bahkan mengering dan umur telah mencapai 3-4 bulan. Pemanenan dilakukan dengan memotong pangkal tangkai/malai buah jewawut dengan panjang sekitar $15-25 \mathrm{~cm}$. Waktu panen yang baik adalah siang hari dan hari cerah. Jewawut jenis pear mempunyai produktivitas 3,5 ton/ha apabila dikelola secara optimal.

\section{Pasca Panen}

Ada tiga hal penting yang harus diperhatikan didalam melakukan pasca panen jewawut antara lain pengeringan, perontokan dan penyimpanan. Pengeringan dilakukan segera setelah panen menggunakan sinar matahari atau dengan mesin pengering. Cara penjemuran dilakukan dengan 
menghamparkan Ikatan tangkai jewawut diatas tikar. Lama pengeringan tergantung keadaan sinar matahari rata-rata 60 jam atau kadar air biji jewawut telah mencapai $12 \%$.

Proses perontokan dilakukan setelah biji kering dengan cara dilirik atau dengan mesin perontok, dan diusahakan biji jewawut jangan sampai terluka. Biji-biji jewawut yang telah dirontokkan dibersihkan atau dipisahkan dari kotoran seperti potongan-potongan tangkai biji dan sebagainya, kemudian masukkan ke dalam karung goni dan diletakkan di gudang, diupayakan kelembaman ruangan gudang stabil. Dalam kondisi normal, penyimpanan bijibijian (jewawut) dengan kelembaban dibawah $14 \%$ dan suhu dibawah $20^{\circ} \mathrm{C}$ memberikan perlindungan yang cukup terhadap perubahanperubahan kimia, biokimia dan mikroorganisme (Sianipar, 2015).

\section{A. Uji Kualitatif Karbohidrat Jewawut}

Jewawut yang telah di panen dihaluskan terlebih dahulu, setelah itu larutkan jewawut pada $1 \mathrm{ml}$ aquades. Masukkan $5 \mathrm{ml}$ reagen benedict dalam tabung reaksi, tambahkan $0,5 \mathrm{ml}$ larutan jewawut lalu panaskan dalam penangas air selama dua menit dan amati perubahan warna.

Semakin banyak konsentrasi monosakarida atau gula pereduksi dalam suatu larutan, akan membuat warna larutan semakin merah bata. Jadi apabila setelah diuji benedict suatu larutan berwarna hijau, maka konsentrasi monosakarida atau gula pereduksinya sedikit. Apabila berwarna kuning maka konsentrasinya lebih banyak, dan apabila berwarna merah bata maka konsentrasinya lebih banyak lagi. Namun apabila larutan tetap berwarna biru, hal itu menandakan bahwa tidak terdapat monosakarida atau gula pereduksi dalam larutan tersebut.

\section{B. Uji Antihipertensi pada Jewawut}

Serbuk jewawut sebanyak 500 $\mathrm{mg}$, ditambahkan $50 \mathrm{ml}$ aquades, didihkan selama 15 menit lalu didinginkan. Dipindahkan $5 \mathrm{ml}$ filtrat pada tabung reaksi, diteteskan pereaksi besi (III) klorida, bila terjadi warna hitam kehijauan menunjukkan adanya golongan senyawa tanin 
yang merupakan senyawa antihipertensi.

\section{PEMBAHASAN}

\section{Potensi Budidaya Tanaman}

\section{Jewawut di Provinsi Jambi}

Jewawut merupakan salah satu tanaman pangan atau sejenis tanaman serealia berbiji kecil. Komoditas ini pernah menjadi makanan pokok di berbagai negara di dunia (termasuk beberapa daerah di Indonesia) sebelum budidaya padi dikenal. Namun, jawawut atau jewawut belum banyak diketahui dan dibudidayakan. Menurut Sirappa (2014) dalam website BPTP Balitbangtan Sulawesi Barat, tanaman jewawut memiliki adaptasi yang baik pada daerah yang curah hujannya rendah sampai daerah kering. Kandungan karbohidrat mendekati beras (75\%), dan kandungan protein lebih tinggi (11\%) dari beras $(7 \%)$, terutama protein gluten. Jewawut mengandung beragam komponen penting yang berpotensi meningkatkan kesehatan tubuh, antara lain senyawa antioksidan, senyawa bioaktif, dan serat, sehingga sangat potensial sebagai salah satu bahan diversifikasi pangan.
Tanaman jewawut dapat di tanam di daerah semi kering dengan curah hujan kurang dari 125 $\mathrm{mm} /$ tahun selama masa partumbuhan yang pada umumnya sekitar 3-4 bulan. Tanaman ini tidak tahan terhadap genangan dan rentan terhadap periode musim kering yang lama. Di daerah tropis, tanaman ini dapat tumbuh pada daerah semi kering sampai ketinggian $2.000 \mathrm{~m}$ dpl. Tanaman ini menyukai lahan subur dan dapat tumbuh baik pada berbagai jenis tanah, seperti tanah berpasir hingga tanah liat yang padat, dan bahkan tetap tumbuh pada tanah miskin hara atau tanah pinggiran. Sedangkan $\mathrm{pH}$ yang cocok untuk tanaman ini adalah 4-8 (Grubben dan Partohardjono, 1996).

Menurut kondisi Geografis Provinsi Jambi (2018), Luas penutup/penggunaan lahan di Provinsi Jambi luas sawah 133,8 ribu hektar, perkebunan 665,3 ribu hektar, luas kawasan hutan di Provinsi Jambi seluas 1.167.638 hektar, pemukiman 0,95\% dan sisanya berupa mangrove, tanah terbuka, tambak/empang dan lainnya. Dengan demikian, Provinsi Jambi sangat potensial untuk 
budidaya tanaman Jewawut sebagai sumber bahan pangan terbarukan.

Teknik budidaya tanaman jewawut dapat dilakukan dengan sistem olah tanah baik sistem olah tanah konvensional (yang menggunakan guludan/bedengan) maupun sistem olah tanah minimum (pada tanah yang subur atau gembur) dan sistem tanpa olah tanah. Prinsip dari sistem olah tanah konvensional (guludan atau bedengan) adalah mengolah tanah secara keseluruhan, yaitu dengan cara manual dan menggunakan cangkul atau linggis kemudian membongkar dan membalik tanah lalu diratakan. Tanah yang telah bersih kemudian dibentuk guludan atau semacam bedengan. Guludan adalah tumpukan tanah yang dibuat memanjang menurut arah garis kontur atau memotong lereng. Tinggi tumpukan tanah sekitar 25-30 cm dengan lebar dasar sekitar 30-40 $\mathrm{cm}$. Guludan dapat diperkuat dengan menanam rumput atau tanaman perdu (Chairani, 2010).

Pengolahan tanah minimum hanya dapat dilakukan pada tanah yang gembur. Tanah gembur dapat terbentuk sebagai hasil dari penggunaan mulsa secara terus menerus dan atau pemberian pupuk (baik pupuk hijau, pupuk kandang, atau kompos) dari bahan organik yang lain secara terus menerus. Penerapan teknik pengolahan tanah minimum perlu disertai dengan pemberian mulsa (Chairani,2010). Untuk sistem tanpa olah tanah, juga bias diterapkan pada tanah-tanah yang subur atau gembur. Sistem tanpa olah tanah merupakan bagian dari konsep olah tanah konservasi yang mengacu kepada suatu sistem olah tanah yang melibatkan pengolahan mulsa tanaman ataupun gulma (tanaman pengganggu).

Persiapan lahan cukup dilakukan dengan penyemprotan, gulma mulai mati dan mengering, lalu direbahkan selanjutnya dibenamkan dalam lumpur (Nursyamsi, 2004). Jewawut dapat ditumpangsarikan dengan tanaman lain seperti dengan padi gogo. Tanaman jewawut berumur lebih cepat sekitar satu bulan dari padi karena berumur 3 bulan, sehingga jewawut tergolong lebih hemat menggunakan air dari pada padi dan jagung. Sedangkan jewawut yang 
ditanam sisipan dengan tanaman jagung memiliki umur panen yang bersamaan dengan jagung.

Benih jewawut tidak disemaikan tetapi dapat langsung di tanam pada suatu media tanam ataupun lahan penanaman dengan cara ditaburkan atau ditanam dalam lubang tanam. Jarak tanam yang cocok untuk tanaman jewawut pada luas areal $2 x$ 3 meter adalah $75 \times 20 \mathrm{~cm}$ atau $70 \mathrm{x}$ $25 \mathrm{~cm}$. Kebutuhan benih 8-10 kg/ha apabila jenis yang ditanam hanya jewawut.

\section{Kandungan Kimia Tanaman Jewawut}

Menurut Singh et al. (2003) pear millet banyak dipakai sebagai sumber pangan yang memiliki protein kasar lebih tinggi 1-2\% dari sorgum, tetapi rendah kandungan asam amino esensial-seperti lisin, triptopan, treonin dan asam amino yang mengandung sulfur. Leder (2004) menyatakan protein jewawut memiliki fraksi protein albumin dan globulin sebesar $22-28 \%$, prolamin sebesar $28-35 \%$ dan glutelin 28 $32 \%$.
Kandungan lemak umumnya lebih tinggi dari sorgum (3-6\%), sebanyak $75 \%$ termasuk asam lemak tidak jenuh rantai panjang (PUFA) dengan jenis PUFA yang terbanyak adalah asam linoleat. Kandungan vitamin jewawut umumnya vitamin $\mathrm{C}$ dan $\mathrm{A}$, sedangkan mineral $\mathrm{Fe}, \mathrm{Ca}, \mathrm{Mg}$, dan Zn. Komposisi kimia Jewawut dapat dilihat pada Tabel 1.

Tabel 1. Komposisi Kimia Jewawut

\begin{tabular}{|l|c|c|c|}
\hline Komponen & $\begin{array}{c}\text { Nurmala } \\
(1997)\end{array}$ & $\begin{array}{c}\text { Leder } \\
(2004)\end{array}$ & $\begin{array}{c}\text { Yanuar } \\
(2009)\end{array}$ \\
\hline $\begin{array}{l}\text { Kadar air } \\
\text { (\%bb) }\end{array}$ & 12.51 & - & 7.61 \\
\hline $\begin{array}{l}\text { Kadar abu } \\
\text { (\%) }\end{array}$ & 3.86 & - & 1.77 \\
\hline $\begin{array}{l}\text { Protein } \\
\text { kasar }(\%)\end{array}$ & 11.38 & - & 7.29 \\
\hline Lemak (\%) & - & - & 1.63 \\
\hline $\begin{array}{l}\text { Serat kasar } \\
(\%)\end{array}$ & 5.65 & 2.2 & - \\
\hline $\begin{array}{l}\text { Karbohidrat } \\
\text { (\%) }\end{array}$ & - & 75 & 81.52 \\
\hline $\begin{array}{l}\text { Energi } \\
\text { kasar(100/g) }\end{array}$ & 386 & 363 & - \\
\hline $\begin{array}{l}\text { P(mg/100 g) } \\
\text { Mg (mg/100 } \\
\text { g) }\end{array}$ & 50 & - & - \\
\hline $\begin{array}{l}\text { Fe (mg/ 100 } \\
\text { g) }\end{array}$ & 122.1 & - & - \\
\hline $\begin{array}{l}\text { Zn (mg/100 } \\
\text { g) }\end{array}$ & 7.8 & 3 & - \\
\hline $\begin{array}{l}\text { Ca (mg/100 } \\
\text { g) }\end{array}$ & 19.8 & - & - \\
\hline $\begin{array}{l}\text { Vitamin A } \\
\text { (mg/100 g) }\end{array}$ & 0.023 & - & - \\
\hline $\begin{array}{l}\text { Vitamin C } \\
\text { (mg/100 g) }\end{array}$ & 26.4 & 2500 & - \\
\hline
\end{tabular}


Biji jewawut mengandung karbohidrat berkisar $60-80 \%$. Sebagian besar butir foxtail millet tidak mengandung gluten (Léder 2004). Jewawut mengandung mineral (kalsium, besi, magnesium, fosfor, seng dan kalium) dan vitamin. Kandungan gizi dari jewawut tiga sampai lima kali lebih baik dari beras dan gandum (Upadhyaya et al. 2011; Dhivya et al. 2015). Jewawut mengandung komponen fitokimia yaitu komponen fenolik dan golongan flavonoid (termasuk tanin), tetapi kandungan taninnya lebih rendah dari sorgum. Warna jewawut disebabkan oleh komponen glikosilvitesin, glikosiloritin, alkali-labil dan asam ferulat. Komponen fenolik ini memiliki sifat antioksidan yang dapat menekan reaksi oksidasi yang merugikan bagi tubuh (Leder 2004).

Jewawut juga mengandung senyawa non gizi yaitu asam fitat dan asam oksalat. Proso millet mengandung asam fitat lebih besar dari beras. Asam oksalat dalam bentuk larut air dan dapat membentuk komplek dengan kalsium. Pearl millet juga mengandung senyawa goitrogen seperti tioamid (Leder 2004). Collet
(2004) menyebutkan jewawut seperti pear millet bebas dari asam sianida ( $\mathrm{HCN})$ yang bersifat toksik.

\section{Potensi Tanaman Jewawut Sebagai Sumber Pangan Terbarukan}

Jewawut merupakan tanaman serealia yang potensial untuk pangan (Amadou et al. 2014). Sampai saat ini jewawut di Indonesia banyak dikenal sebagai pakan burung, sedangkan pemanfaatannya untuk pangan belum banyak diketahui. Kandungan nutrisi jewawut terutama karbohidrat tidak jauh berbeda dengan beras maupun jagung bahkan lebih tinggi dibanding gandum. Jewawut memiliki zat anti nutrisi berupa asam fitat (Léder 2004). Tanaman jawawut mempunyai beberapa kelebihan dibandingkan dengan tanaman bijibijian lain karena mudah dibudidayakan, dapat ditanam pada lahan kering atau lahan marginal, tingkat adaptasi tinggi, produksi tanaman cukup tinggi dan mempunyai banyak manfaat yaitu bisa digunakan sebagai bahan pangan maupun pakan ternak.

Jewawut berpotensi untuk dikembangkan dalam rangka memperkuat ketahanan pangan 
sebagai sumber karbohidrat pengganti beras. Tanaman ini tersebar hampir di seluruh Indonesia seperti pulau Buru, Jember, Sulawesi Selatan seperti Enrekang, Sidrap, Maros, Sulawesi Barat yaitu Polewali Mandar, Majene dan daerah lainnya. Jewawut memiliki keunggulan dibanding dengan tanaman sumber karbohidrat lain, seperti dapat tumbuh pada hampir semua jenis tanah termasuk tanah kurang subur, tanah kering, mudah dibudidayakan, umur panen pendek dan kegunaannya beragam (Suherman et al., 2009). Jewawut mengandung karbohidrat $74,16 \%$ lebih tinggi dibanding gandum yang hanya $69 \%$. Ini menunjukkan bahwa jewawut berpotensi sebagai sumber pangan fungsional, terutama sebagai sumber energi (Rauf dan Lestari 2009). Berdasarkan data tersebut, Jewawut sangat berpotensi sebagai sumber karbohidrat terbarukan karena memiliki karbohidrat setara dengan atau lebih daripada beras dan dapat di kembangkan di Provinsi Jambi.

\section{Bioaktivitas Tanaman Jewawut sebagai Antihipertensi}

Hipertensi merupakan penyebab kematian nomor 3 (tiga), setelah stroke dan tuberkulosis. Jumlahnya mencapai $6,8 \%$ dari proporsi penyebab kematian pada semua umur di Indonesia. Prevalensi hipertensi di Indonesia sebesar 30\% dengan insiden komplikasi penyakit kardiovaskuler lebih banyak pada perempuan sebesar $52 \%$ dibandingkan pada laki-laki sebesar 48\% (Departemen Kesehatan RI, 2010). Jumlah tersebut akan terus tinggi lagi mengingat hipertensi merupakan faktor utama penyebab penyakit jantung dan kardiovaskuler (Departemen Kesehatan RI, 2009). Berikut merupakan data profil kesehatan di Provinsi Jambi

Tabel 2. Profil Kesehatan Provinsi Jambi

\begin{tabular}{|l|c|c|c|c|c|}
\hline \multirow{2}{*}{ Komponen } & \multicolumn{5}{|c|}{ Persentase (\%) } \\
\cline { 2 - 6 } & 2013 & 2014 & 2015 & 2016 & 2017 \\
\hline $\begin{array}{l}\text { Infeksi akut } \\
\text { dan } \\
\text { Pernafasan }\end{array}$ & 30.39 & 34.14 & 35.3 & 37.11 & 15.4 \\
\hline Gastritis & 10.3 & 11.37 & 14.82 & 7.92 & 11.97 \\
\hline Hipertensi & 12.63 & 12.16 & 13.89 & 10.3 & 14.46 \\
\hline Diare & 8.83 & 7.56 & 8.71 & 4.74 & 7.12 \\
\hline $\begin{array}{l}\text { Penyakit } \\
\text { Kulit Alergi }\end{array}$ & 9.53 & 8.21 & 7.79 & 8.28 & 6.26 \\
\hline
\end{tabular}

Sumber : BPS Prov Jambi (2018), Profil Kesehatan Provinsi Jambi (2015 \& 2016). 
Berdasarkan data tersebut, penyakit Hipertensi di Provinsi Jambi merupakan penyakit ketiga setelah penyakit Infeksi Saluran pernafasan dan Gastritis. Sehingga, dibutuhkan senyawa aktif yang memiliki aktivitas sebagai antihipertensi seperti senyawa Flavonoid. Menurut Adha (2009), flavonoid memiliki efek anti tumor, immunostimulan, analgesik, anti radang (anti inflamasi), anti virus, anti bakteri, anti HIV, anti diare, anti hepatotoksik, anti hiperglikemik dan sebagai vasodilator. Flavonoid juga memiliki potensi sebagai antioksidan. Antioksidan berguna untuk mencegah penuaan akibat zat-zat radikal bebas yang menyebabkan kerusakan jantung. Flavonoid berguna untuk menurunkan tekanan darah dengan zat yang dikeluarkan yaitu nitric oxide serta menyeimbangkan beberapa hormon di dalam tubuh. Menurut Jouad, et al (2001), campuran flavonoid dapat meningkatkan urinasi dan pengeluaran elektrolit pada tikus normotensi. Kecepatan filtrasi glomerulus (GFR) memperlihatkan peningkatan yang signifikan setelah pemberian flavonoid.
Selain itu, Jewawut juga mengandung senyawa tanin. Senyawa fitokimia alkaloid tanin memiliki efek dalam bidang kesehatan sebagai antihipertensi. Tanin mengurangi pengerasan pembuluh darah. Jika pengerasan tidak terjadi, peredaran darah lancar sehingga kerja jantung tidak terlalu berat dan potensi stroke bisa hilang (Diennazola, 2012). Tanin juga merupakan senyawa aktif metabolit sekunder yang diketahui mempunyai beberapa khasiat yaitu sebagai astringen, anti diare, anti bakteri dan antioksidan. Tanin juga dapat berfungsi sebagai antioksidan biologis. Antioksidan dalam pengertian kimia, merupakan senyawa pemberi elektron.

Dengan demikian, Jewawut memiliki potensial dalam bidang pangan dan kesehatan serta dapat menjadi sumber obat antihipertensi sebagai salah satu solusi mengatasi penyakit hipertensi di Provinsi Jambi.

\section{KESIMPULAN}

1. Jewawut mengandung karbohidrat $74,16 \%$ lebih tinggi dibanding gandum yang hanya $69 \%$. Ini menunjukkan bahwa 
jewawut berpotensi sebagai

sumber pangan fungsional, terutama sebagai sumber

energi. Berdasarkan data tersebut, jewawut sangat berpotensi sebagai sumber karbohidrat terbarukan karena memiliki karbohidrat setara dengan atau lebih daripada beras dan dapat di kembangkan di Provinsi Jambi.

2. Senyawa metabolit sekunder fitokimia tanin pada tanaman jewawut yang berfungsi sebagai antihipertensi, merupakan salah satu alternatif untuk mengatasi penyakit hitertensi yang merupakan penyakit ketiga tertinggi di Provinsi Jambi.

\section{DAFTAR PUSTAKA}

Adha, Citra A. 2009. Pengaruh Pemberian Ekstrak Etanol Daun Alpukat (Persea Americana Mill.) terhadap Aktivitas Diuretik Tikus Putih Jantan Spraguey-Dawley. Fakultas Kedokteran Hewan IPB. Bogor.

Amadou, I, ME.Gounga, Yong-Hui Shi, \& Guo-Wei Le. 2014. Fermentation and heat-moisture treatment induced changes on the physicochemical properties of foxtail millet (Setaria italica) flour. Journal Food and
Bioproducts Processing. 92(1) : 38-45.

Badan Pusat Statistik. 2018. Luas Panen dan Produksi Beras 2018. Jakarta : Badan Pusat Statistik.

BPS Provinsi Jambi. 2018. Provinsi Jambi dalam Angka 2018. Jakarta : V. Salim Media Indonesia.

Chairani, 2010. Jewawut. diakses dari.

http://balitsereal.litbang.deptan.g o.id.

Collet, I. J. 2004. Forage Sorghum and Millet. Agfact P.2.5.41, Third Edition.

Departemen Kesehatan RI. 2009. Hipertensi Faktor Risiko Utama Penyakit Kardiovaskuler. Pusat Komunikasi Publik Sekretariat Jenderal Departemen Kesehatan Republik Indonesia. Jakarta : Press Kemenkes RI.

Departemen Kesehatan RI. 2010. Hipertensi Penyebab Kematian No. 3, Pusat Komunikasi Publik Sekretariat Jenderal Departemen Kesehatan Republik Indonesia. Semarang Dinas Kesehatan Provinsi Jawa Tengah.

Dhivya, AB., S. Subashini, R. Chandrababu \& J. Ramalingam. 2015. Establishment of MilletDB: TNAU Released Millet Varieties with their Morphological Traits. International Journal of Computer Applications. 111(14) : 24-26.

Diennazola, Renda, 2012, Manfaat Si Hitam Langka. Tabloid Agribisnis Dwi Mingguan, http://www.agrinaonline.com/sho $w$ article. php?rid $=12 \&$ aid $=3530$.

Dinas Pertanian Provinsi Jambi. 2012. Upaya Peningkatan Ketahanan Pangan Di Provinsi Jambi. 
Grubben, G. J. H. dan S. Partohardjono. 1996. "Plant Resources of South-East Asia". Prosea. Bogor.

Ilmudasar. $2018 . \quad$ "Cara Pengendalian Hama dan Penyakit Tanaman Jewawut. https://ilmudasar.id/carapengendalian-hama-danpenyakit-tanaman-jewawut/. Diakses tanggal 3 September 2019.

Jouad $H$, Dubois MAL, Lyoussi $B$, Edduks M. 2001. Effects of The Flavonoids Extract from Spregularia Pupurea Pers, On Arterial Blood Pressure and Renal Function in Normal and Hypertensive Rats. Journal of Ethnopharmacology. Vol. 76: 159-163.

http://www.sciencedirect.com/sci ence/journal/03788741.

Léder, I. 2004. Sorghum and Millets.Cultivated Plants, Primarily As Food Sources. Department of Technology, Central Food Research Institute. Hungary. Encyclopedia of Life Support Systems (EOLSS).

Nurmala, T. 1997. Serealia. Jakarta: Rineka Cipta.

Nursyamsi, D. 2004. Beberapa Upaya untuk Meningkatkan Produktivitas Tanah di Lahan Kering. Makalah Pribadi Falsafah Sains Pasca Sarjana. Institut Pertanian Bogor. Bogor. $24 \mathrm{hlm}$.

Pemerintah Indonesia. 2002. Peraturan Pemerintah No.68 Tahun 2002 tentang Ketahanan Pangan. Lembaran Negara Republik Indonesia Tahun 2002
No 142. Jakarta: Sekretariat Negara.

Rauf A.W, Lestari M.S. 2009. Pemanfaatan Komoditas Pangan Lokal sebagai Sumber Pangan Alternatif di Papua. Balai Pengkajian Teknologi Pertanian Papua.

Kementerian Kesehatan RI. 2018. Hasil Utama Riskesdas 2018. Jakarta: Kementerian Kesehatan Badan Penelitian dan Pengembangan Kesehata

Rosenthal, A. J. 1999. Food Texture, Measurement and Perception. Maryland : Aspen Publication.

Sianipar M. 2015. Materi Penyuluhan Tanaman Pangan. Diakses pada http://margarethasianipar.blogsp ot.com/2015/06/materipenyuluhan-7.html. Tanggal 25 Mei 2018.

Singh V, Moreau R.A, Hicks K.B. 2003. Yield and Phytosterol Composition of Oil Extracted from Grain Sorghum and its WetMilletFractions. Cereal Chemis 80 (2): 126-129.

Sirappa, Marthen P. 2014. Survey Pengelolaan Sumber Daya Genetik. http://sulbar.litbang. pertanian.go.id/ind/index.php/info -teknologi/365-potensi-danteknologi-budidaya-tanamanjewawut-setaria-italica-disulawesi-barat. Diakses tanggal 27 Mei 2018.

Suherman O, Zairin M, Awaluddin. 2009. Keberadaan dan Pemanfaatan Plasma Nutfah Jewawut di Kawasan Lahan Kering Pulau Lombok. http://medicafarma.blogspot.com /2008/11/ekstraksi.html.11 Januari 2011. 
Upadhyaya HD, Ravishankar CR, Narasimhudu Y, SarmaNDRK, Singh SK, Varshney SK, Reddy VG, SinghS, Parzies HK, Dwivedi SL. 2011. "Identificationof trait-specific germplasm and developing aminicore collection for efficient use of foxtail milletgenetic resources in crop improvement". FieldCropRes. Vol. 124:459-467.
Yanuar, W. 2009. "Aktivitas Antioksidan dan Imunomodulator Serealia Non-Beras". Tesis. Bogor : Sekolah Pasca Sarjana I 